\title{
Late Pleistocene plant macrofossils from the Thimi Formation (Madhyapur Thimi section) of the Kathmandu Valley, central Nepal
}

\author{
Sudarshan Bhandari ${ }^{1}$, *Khum N. Paudayal ${ }^{1}$, and Arata Momohara ${ }^{2}$ \\ ${ }^{1}$ Central Department of Geology, Tribhuvan University, Kirtipur, Kathmandu, Nepal \\ ${ }^{2}$ Faculty of Horticulture, Chiba University, Matsudo 648, Chiba 271-8510, Japan \\ (*Email: khum99@gmail.com)
}

\begin{abstract}
The Late Pleistocene plant macrofossils from the Thimi Formation of the Kathmandu Valley have been reported in this paper. On the basis of 71 taxa from 39 families, seven plant macrofossil assemblages T-1 to T-7 were described from 18.5 $\mathrm{m}$ thick section of the Thimi Formation exposed at Madhyapur Thimi, Bhaktapur. Pinus, Abies, Tsuga, Carpinus, Sambucus, Rubus, Eurya, Potentilla and Scirpus are the common elements in the Thimi Formation. It is found that the cool temperate elements (Abies, Pinus, Tsuga, Picea, Taxus) were dominated over warm climatic elements (Quercus, Eurya, Pyracantha, etc.) during the deposition of the Thimi Formation. The underlying Gokarna Formation exhibited subtropical to warm temperate vegetation with the dominance of subtropical elements such as Eurya, Ficus, Zizyphus, etc. over temperate elements like Betula, Tsuga and Abies. During the depositional period of the Thimi Formation, this subtropical to warm temperate type of vegetation shifted to warm to cold temperate type with the abundant presence of gymnosperms and other evergreen taxa.
\end{abstract}

Keywords: Plant macrofossils, paleoclimate, paleovegetation, Late Pleistocene, Thimi Formation, Kathmandu Valley

Received: December 25, 2009

Revision accepted: April 8, 2010

\section{INTRODUCTION}

The Kathmandu Valley is one of the several tectonic intermontane basins formed within the Lesser Himalayan belt. Thick unconsolidated sediments have deposited in and around the Paleo-Kathmandu Lake to fill the basin since the Late Pliocene to Holocene (Yoshida and Igarashi 1984). The total thickness of the basin fill sediments reaches more than $500 \mathrm{~m}$ in the central part (Sakai et al. 2001; Sakai et al. 2002). The basin fill sediments are fluvio-lacustrine, fluvial to fluviodeltaic in origin and considered to have been resulted from damming in the southern part of the valley. The main purpose of this study is to discuss the climate and vegetation of the Late Pleistocene based on the plant macrofossils from the Thimi Formation. The fluvio-lacustrine sediment of the Kathmandu Valley is one of the best deposits to study the Late Pleistocene vegetation and climate in Nepal.

Plant macrofossils are very important to obtain floristic data in the species level and information is more local than compared to the information provided by palynomorphs. We have obtained more detailed plant macrofossil data from the same Thimi section compared to palynomorph assemblages reported earlier by Paudayal (2005). Fossil pollen in the basin was studied stratigraphically by Igarashi et al. (1988), Nakagawa et al. (1996), Fuji and Sakai (2001), Paudayal and Ferguson (2004) and Paudayal (2005, 2006). The sediments outcropped in the valley included well preserved plant macrofossils that have been reported earlier by Ooi (2001). A detailed study was performed in the Dhapasi section of the Gokarna Formation by Bhandari et al. (2009). The palynological data from earlier studies and the supplementary information obtained from the macrofossil analysis will be helpful to understand the paleovegetation, paleoclimate and paleoenvironment during the Late Pleistocene in the Kathmandu Valley and its surroundings.

\section{GEOLOGICAL SETTINGS}

The Kathmandu Valley is situated in the central part of Nepal and is an oval shaped basin stretching about $30 \mathrm{~km}$ in the east-west direction and $25 \mathrm{~km}$ in the north-south direction. The basin is situated in the Midland of the Lesser Himalaya and bounded by the Mahabharat Lekh to the south and Shivapuri Lekh in the north. The basement geology of the basin consists of sedimentary rocks of the Paleozoic Phulchauki Group and Pre-Cambrian gneisses in the north of the basin which is referred to as Kathmandu Complex or Gosainkund Crystalline Nappe (Stöcklin and Bhattarai 1977; Rai et al. 1998).

Based on earlier geological mapping the basin sediments were divided into eight lithostratigraphic units (Yoshida and Igarashi 1984; Igarashi et al. 1988; Yoshida and Gautam 1988). After the deposition of the Lukundol Formation (Late Pliocene to Early Pleistocene), there was an activation of the Main Boundary Thrust (MBT) at the southern part which 


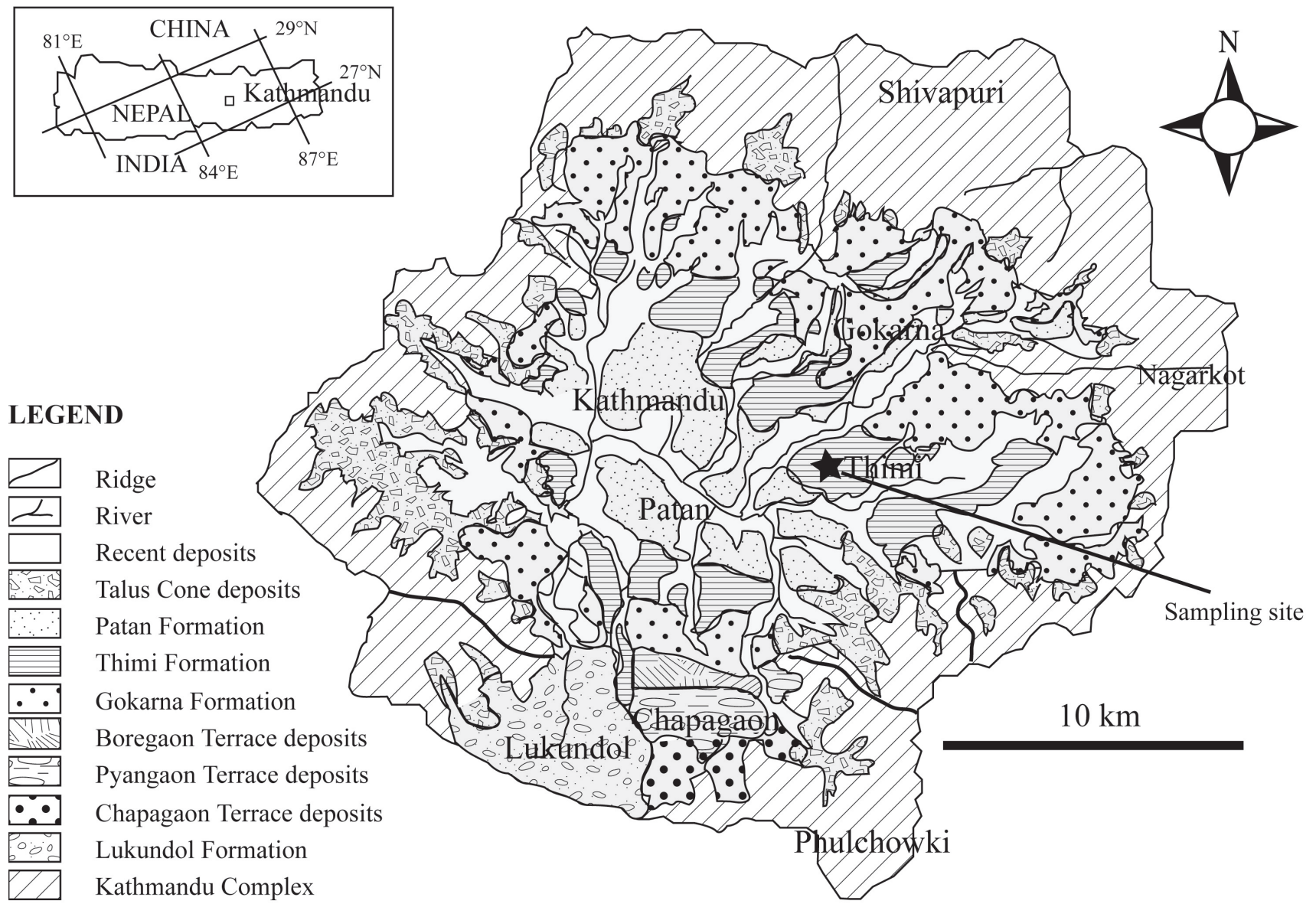

Fig. 1: Geological setting of the Kathmandu Valley (Redrawn after Yoshida and Igarashi 1984; Yoshida and Gautam 1988) with the sample location within the Thimi Formation

resulted the old lake to shift northwards leading subsequently to the formation of three terraces (Pyanggaon, Chapagaon and Boregaon) in the south and thus creating a new environment for the deposition of younger sediments named as Gokarna, Thimi and Patan formations in the northern and central part of the basin.

The Thimi Formation is well exposed at Thimi (coordinates $27^{\circ} 40^{\prime} 30^{\prime \prime} \mathrm{N}$ and $85^{\circ} 23^{\prime} 30^{\prime \prime} \mathrm{E}$ ) at an altitude of $1300 \mathrm{~m}$ in the eastern part of the Kathmandu Valley around the Madhyapur Thimi Municipality on the left side of Arniko Highway (Fig. 1). This section is about $18.5 \mathrm{~m}$ in thickness and composed of alternating layers of carbonaceous clay, silty clay, silt and fine to coarse grained sand deposited in deltaic to fluvio-lacustrine environment (Fig. 2). The samples for plant macrofossils were taken from the organic rich layer of silt and fine sand because the organic rich sediment is generally deposited along with silt or fine to medium-grained sand. The typical characteristic feature to distinguish the Thimi Formation from the underlying Gokarna Formation is the dominance of fine sediments over coarse sediments. Different sedimentary structures like planar, trough-cross laminations, convolute bedding are common in the Thimi
Formation. The ripples are distorted indicating paleoearthquakes (Gajurel et al. 1998). The radiocarbon ages of this section of the Thimi Formation from the bottom and top layer were found to be $>37,900$ and $>41,700$ years BP, respectively (Paudayal 2005). The result obtained by the radiocarbon dating $(43,180$ and 45,140 years BP) from the same section by Gajurel (1998) also shows the similar age as that of Paudayal (2005).

\section{MATERIALS AND METHODS}

The organic rich clay, silt, silty-sand and micaceous fine sand layers of the Thimi Formation contain abundant plant macrofossils (fruit and seeds). Plant macrofossils were obtained by sieving about 5 kilograms of sample, which was taken from each organic rich horizon with a $0.5 \mathrm{~mm}$ mesh sieve in water. The residue thus obtained from $0.5 \mathrm{~mm}$ sieve was sorted according to different size of plant fragments by $4 \mathrm{~mm}, 2 \mathrm{~mm}$ and $1 \mathrm{~mm}$ sieves and washed with water to facilitate observation. The material was studied under OLYMPUS SZ-PT binocular microscope at x100 magnifications and plant parts (seeds, fruits and leaves) were 


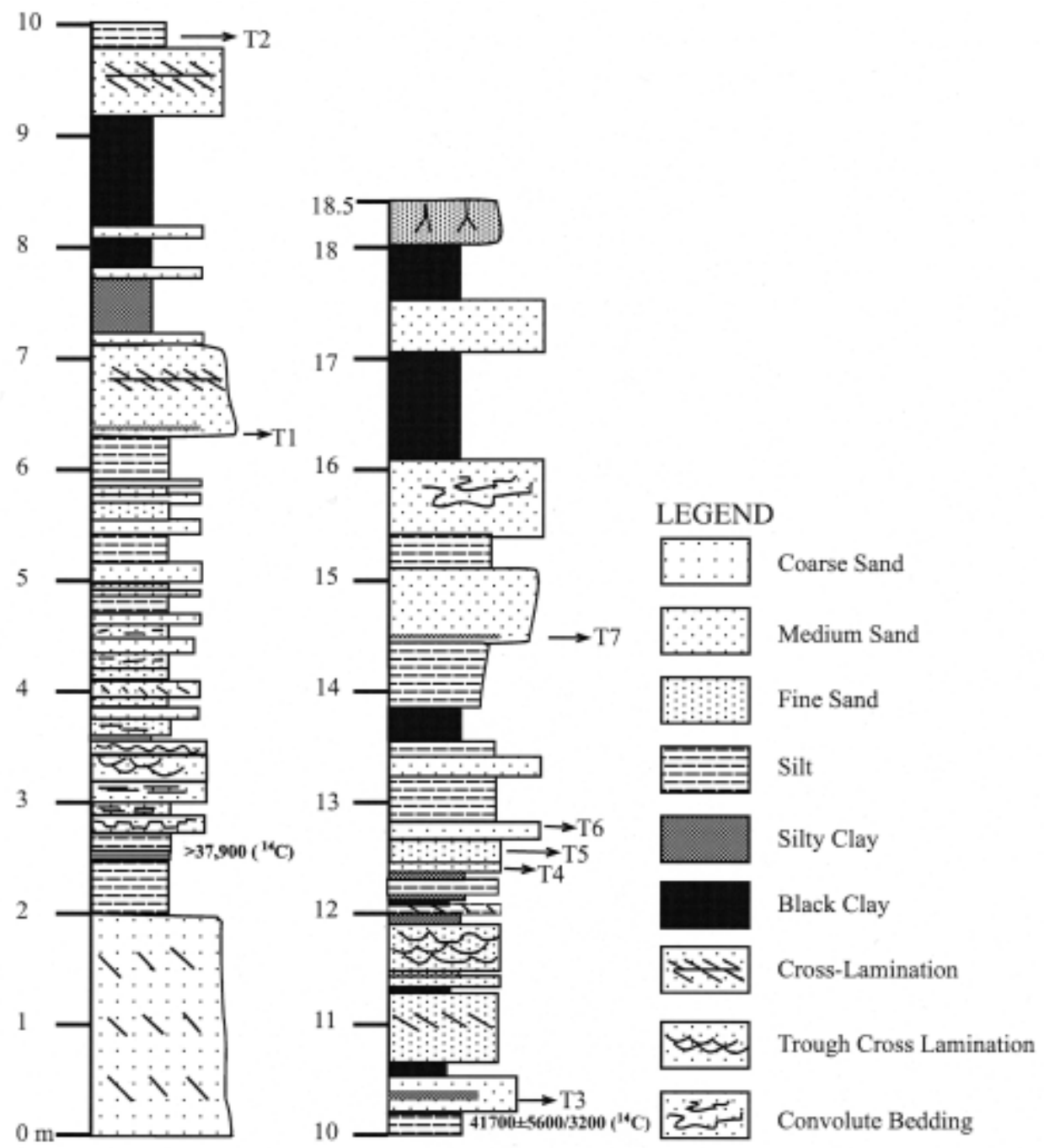

Fig. 2: Lithological details of the Madhyapur Thimi section of the Thimi Formation

picked up using brush and needle. The plant macrofossils were identified up to genus and species level as far as possible and the light microscope photographs of each individual taxon were taken with a NIKON Digital Camera DXM 1200F attached with the microscope. For the identification of the seeds and fruits, the important points to be noted are generally the shape, the size and peculiarities of the surface. The colour of the seed surface is the next important clue for the identification. The shape, size and position of the attachment scar i.e. hilum is the other important point for the accurate identification of the taxa either to the genus or to the species level (Martin and Barkley 1973). The presence of other noticeable external features like wings, pappus, spines, awns or hairs also provided the important information to place the seeds in correct taxonomic position. The ecological distribution of the listed taxa is referred from Stainton (1972), Malla et al. (1986) and Press et al. (2000).

\section{DESCRIPTION OF INDIVIDUAL FOSSIL}

From the Thimi Formation, 71 taxa from 39 families were identified to the genus level and some of them up to species level. Identified fossil taxa are listed according to Engler and Prantl's classification system. The morphological character of each taxon is described below.

\section{Pteridophyta}

Selaginella remotifolia Spring (Fig. 3, No. 1)

Material studied: Macrospore

Shape in outline round, diameter of the macrospore is 0.8 $\mathrm{mm}$. Surface finely reticulated by polygonal mesh design with irregular ridges. Light green in appearance.

Ecology: Occurs in temperate regions. 


\section{Gymnosperms}

TAXACEAE

Taxus wallichiana Zucc. (Fig. 3, No. 2)

Material studied: Seed

Shape in outline ovoid, flattened at the apical part, 6.0 $\mathrm{mm}$ long and $5.0 \mathrm{~mm}$ wide, elliptic to nearly circular basal part. Presence of vertical striations on the surface of the seed. Seed surface brown, lusterless and woody.

Ecology: Common vegetation in the coniferous forests.

\section{PINACEAE}

Abies sp. (Fig. 3, No. 3)

Material studied: Seed

Shape in outline flattened and triangular, $5.4 \mathrm{~mm}$ long and $3.0 \mathrm{~mm}$ wide. The surface of seed coat has fine, wavy markings that run diagonally or nearly crosswise. Some resin vesicles included in seed coat are characteristic of Abies and Tsuga, whereas Pinus and Picea seeds do not include vesicles. The size of vesicles in Abies seed is larger than that of Tsuga.

Ecology: Growing in mixed forest with Oak, Rhododendron, Betula and Tsuga.

Picea smithiana (Wall.) Boiss. (Fig. 3, No. 4)

Material studied: Leaf (needle)

Shape in outline needle shaped, quadrangular in crosssection, laterally flattened, $4.8 \mathrm{~mm}$ long and $1.4 \mathrm{~mm}$ wide. Four bands of stomatal row are distributed on four sides of leaf.

Ecology: Common taxa in coniferous forests.

Pinus roxburghii Sarg. (Fig. 3, No. 5)

Material studied: Leaf (needle)

Shape in outline needle shaped, flattened, $8.0 \mathrm{~mm}$ long and $1.1 \mathrm{~mm}$ wide. Minute serration along margin with pointed tip, fan shaped in cross section, more or less compressed dorsoventrally, stomatal openings are clearly visible on the surface of the needle.

Ecology: Common species in coniferous forests.

Tsuga dumosa (D. Don) Eichler (Fig. 3, No. 6)

Material studied: Leaf (needle)

The lamina is flattened and lorate, $2.5 \mathrm{~mm}$ long and 0.7 $\mathrm{mm}$ wide with distinct mid rib and the petiole is $1 \mathrm{~mm}$ long and twisted at the base of the lamina.

Ecology: Common species in coniferous forests.

\section{Angiosperms}

\section{DICOTYLEDONS}

\section{BETULACEAE}

Alnus sp. (Fig. 3, No. 7)

Material studied: Fruiting scale of infructescence

The fruiting scale is fan-shaped, $3.0 \mathrm{~mm}$ long, $1.7 \mathrm{~mm}$ wide, woody and thick. The uppermost fringe of the scale is somewhat thickened and consists of low lobes. Adaxial surface of the scale is longitudinally striated.

Ecology: Wetland and secondary forests.

Carpinus sp. (Fig. 3, No. 8)

Fruit is generally triangular in outline and lenticular in transverse section, $3.3 \mathrm{~mm}$ long and $2.8 \mathrm{~mm}$ wide. The fruit surface bears three or more prominent longitudinal ridges running from the base to apex on both faces.

Ecology: Occurs in temperate forests.

\section{FAGACEAE}

Quercus sp. (Fig. 3, No. 9)

Material studied: Nut

Shape in outline globose, subcylindric to triangular and brown or yellowish in colour, $11.0 \mathrm{~mm}$ long and $6.5 \mathrm{~mm}$ wide. The nut is smooth with fine striations on the surface. Attachment of cupules is observed in some of the fruits.

Ecology: Subtropical to temperate forest mixed with Pinus and Rhododendron.

\section{MORACEAE}

Morus sp. (Fig. 3, No. 10)

Material studied: Endocarp

Shape in outline oval-lenticular to ovoid, $1.6 \mathrm{~mm}$ long and $1.2 \mathrm{~mm}$ broad, light-colored, slender attachment stalk oppressed to the thinner edge; seed wall is woody but thin.

Ecology: Occurs in shady Oak forests.

\section{POLYGONACEAE}

Persicaria hydropiper (Meisn.) H. Gross (Fig. 3, No. 11)

Material studied: Fruit

Shape in outline ovate and trigonous achene with subacute apex, $2.9 \mathrm{~mm}$ long and $1.8 \mathrm{~mm}$ wide. The fruit wall is formed from cuboidal or columnar sclereids with strongly thickened and often undulate walls. The wall ligneous and the surface is rough and lusterless. 

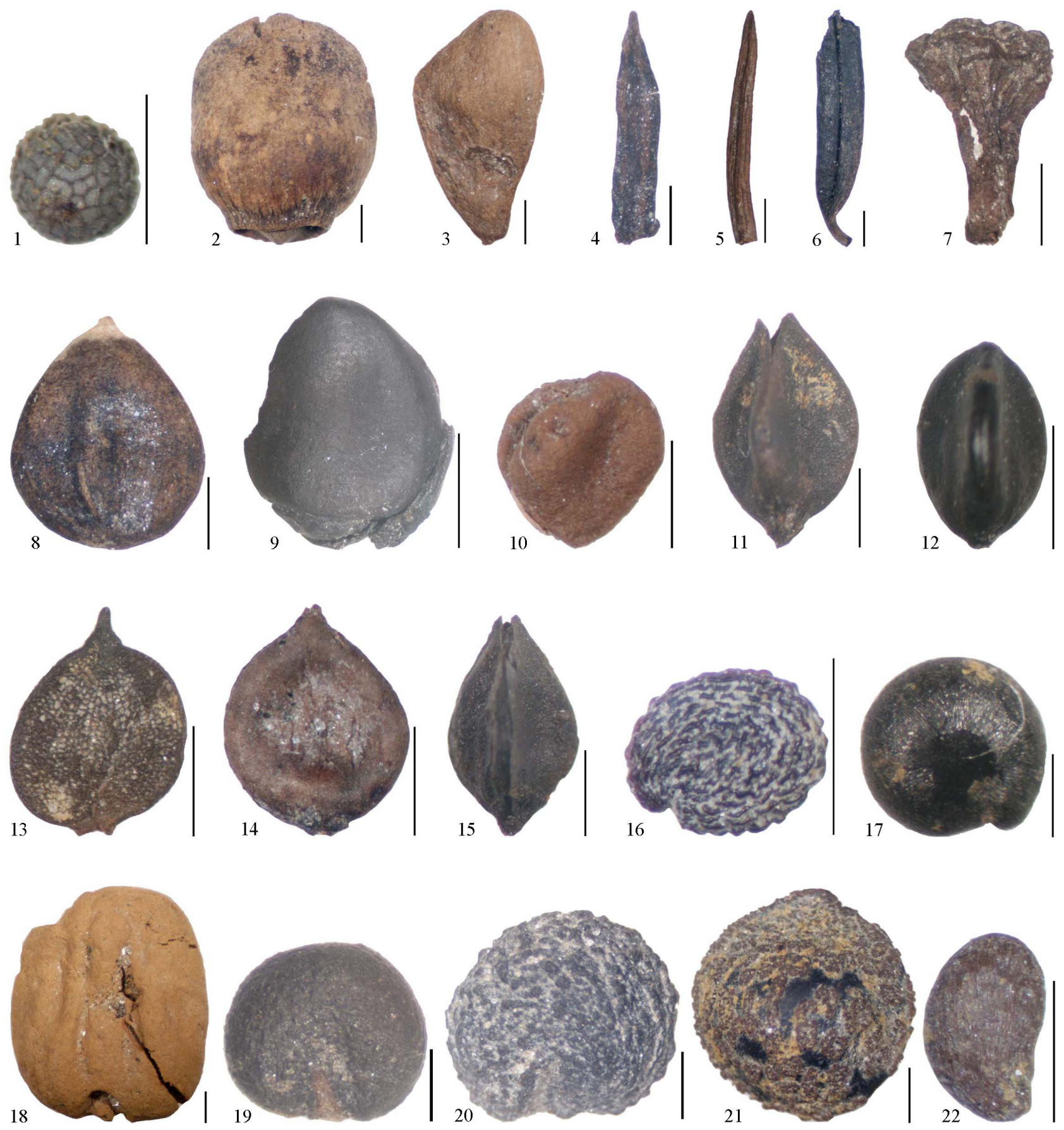

Scale 1-8,10-22:1mm,9:5mm

Fig. 3: 1. Selaginella remotifolia (macrospore) 2. Taxus wallichiana (seed) 3. Abies sp. (seed) 4. Picea smithiana (leaf) 5. Pinus roxburghii (needle) 6. Tsuga dumosa (leaf) 7. Alnus sp. (fruiting scale) 8. Carpinus sp. (fruit) 9. Quercus sp. (fruit) 10. Morus sp. (endocarp) 11. Persicaria hydropiper (fruit) 12. Persicaria longiseta (fruit) 13. Persicaria nepalensis (fruit) 14. Persicaria sp. cf. P. scabra 15. Rumex sp. (fruit) 16. Stellaria sp. (seed) 17. Chenopodium album (seed) 18. Magnolia sp. (seed) 19. Schisandra sp. A (seed) 20. Schisandra sp. B (seed) 21. Lauraceae (seed) 22. Batrachium sp. (fruit) 
Ecology: Stream side vegetation.

Persicaria longiseta (Bruyn) Kitag. (Fig. 3, No. 12)

Material studied: Fruit

Shape in outline triangular to lensoid, $1.9 \mathrm{~mm}$ long and $1.0 \mathrm{~mm}$ broad. The fruit is black and the surface smooth and shiny.

Ecology: Stream side vegetation.

Persicaria nepalensis (Meisn.) H.Gross (Fig. 3, No. 13)

Material studied: Fruit

Fruit ovate to lensoid in outline, flattish, $2.0 \mathrm{~mm}$ long and $1.6 \mathrm{~mm}$ wide. The apex is somewhat abruptly pointed whereas the base is flat. The whole structure is plano-convex. The surface is rough with fine sculpture and barely lustrous.

Ecology: Stream side vegetation.

Persicaria sp. cf. P. scabra (Moench.) Mold. (Fig. 3, No. 14)

Material studied: Fruit

Shape in outline triangular, $2.2 \mathrm{~mm}$ long and $1.7 \mathrm{~mm}$ wide. The fruit is flat with shiny surface. The side of the surface is slightly concave and the apex is sub-acute.

Ecology: Common taxa in wetland in flood plain and paddy fields.

Rumex sp. (Fig. 3, No. 15)

Material studied: Fruit

Shape in outline triangular, $2.5 \mathrm{~mm}$ long and $1.5 \mathrm{~mm}$ broad. The base and apex pointed. The surface of the fruit is smooth and shiny.

Ecology: Stream side vegetation.

\section{CARYOPHYLLACEAE}

Stellaria sp. (Fig. 3, No. 16)

Material studied: Seed

Shape in outline elliptic to circular and is flattened. The campylotropous seed is $1.0 \mathrm{~mm}$ long and $1.1 \mathrm{~mm}$ broad. Reniform, ovate with a distinct marginal notch, slightly compressed. The seed surface is lusterless to highly glossy with the presence of wrinkles.

Ecology: Occurs in waste grounds.

\section{CHENOPODIACEAE}

\section{Chenopodium album L. (Fig. 3, No. 17)}

Material studied: Seed
Shape in outline round. The campylotropous seed is 1.1 $\mathrm{mm}$ long and $1.0 \mathrm{~mm}$ broad. The seed surface is smooth and lustrous. Hilum is in the marginal notch. The characteristic feature is the presence of radial striations in its surface which is also a clue for the identification to the genus level.

Ecology: Cosmopolitan, usually occurs in subtropical to temperate regions.

\section{MAGNOLIACEAE}

Magnolia sp. (Fig. 3, No. 18)

Material studied: Seed

Shape in outline broad ovate, $7.8 \mathrm{~mm}$ long, $6.5 \mathrm{~mm}$ broad and $2.7 \mathrm{~mm}$ thick, asymmetrical, low lengthwise ridge or shallow groove in the middle of a face and a small hole at the broader end. Wall somewhat bony. Outer surface almost smooth with an elongate median raphe on the ventral side.

Ecology: Constituent of the bottomland wetland forests.

\section{SCHISANDRACEAE}

Schisandra sp. A (Fig. 3, No. 19)

Material studied: Seed

The campylotropous seed is reniform and C-shaped in outline, $2.6 \mathrm{~mm}$ long and $2.9 \mathrm{~mm}$ wide, curved in plane of bisymmetry and rounded at both ends. Seed surface smooth and seed coat hard. Woody.

Ecology: Constituent of wetland forests.

Schisandra sp. B (Fig. 3, No. 20)

Material studied: Seed

Shape in outline reniform to cashew shaped, $3.0 \mathrm{~mm}$ long and $3.5 \mathrm{~mm}$ wide. The campylotropous seed contains some rough markings on the surface. Hilum situated in the ventral sinus, raphe originating at the hilum and running a medial course along the dorsal curve.

Ecology: Constituent of wetland forests.

\section{LAURACEAE}

Lauraceae gen. et sp. indet. (Fig. 3, No. 21)

Material studied: Seed

Shape in outline subglobose to globose, $4.3 \mathrm{~mm}$ long and $4.1 \mathrm{~mm}$ broad. Single seeded, seed-wall is thick and composed of uniserate layer of compactly arranged columnar cells. Seed surface is rough.

Ecology: Occurs in temperate to tropical forests.

RANUNCULACEAE 

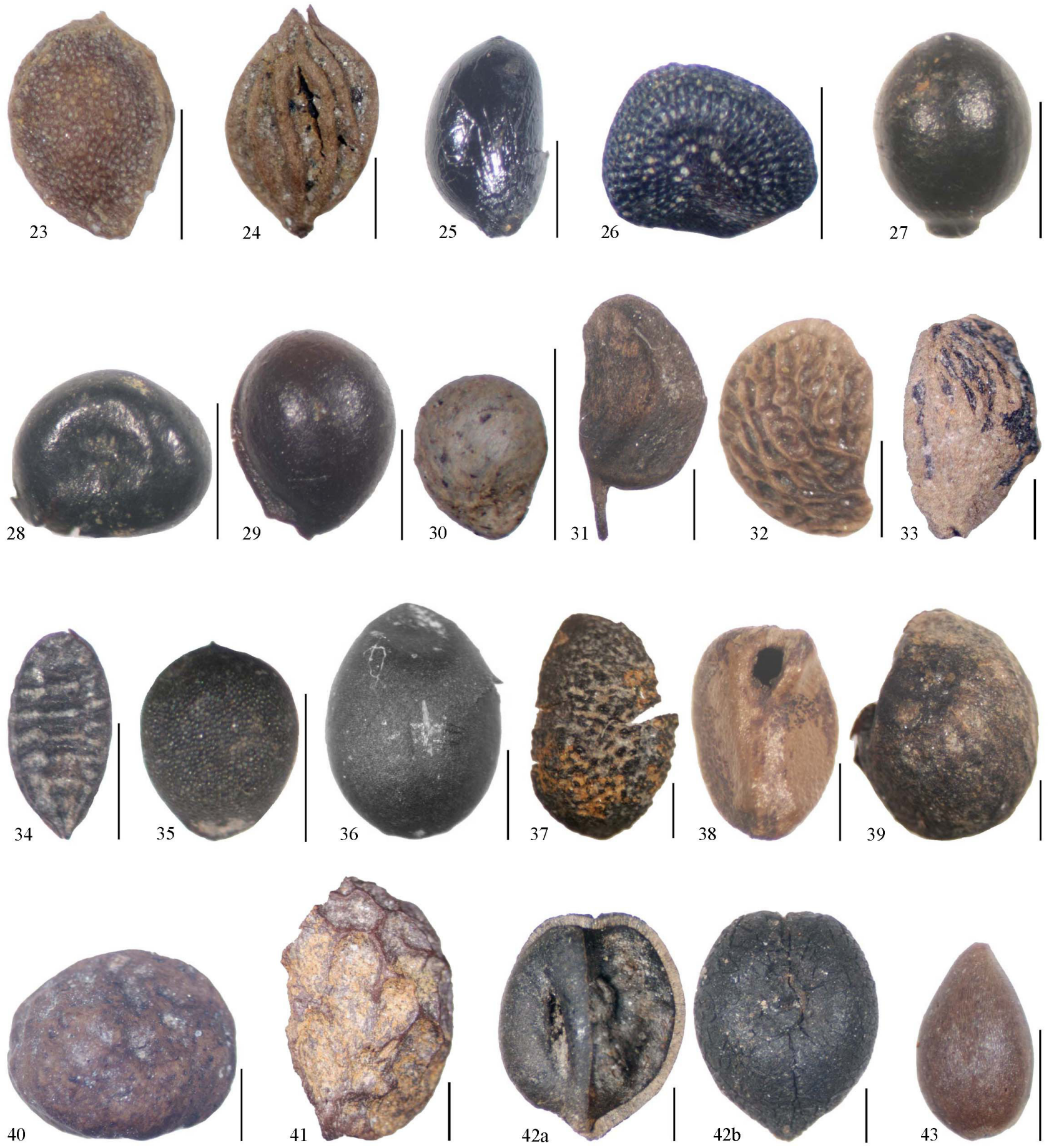

Scale $23-43: 1 \mathrm{~mm}$

Fig. 4: 23. Ranunculus sp. (fruit) 24. Thallictrum sp. (fruit) 25. Ranunculaceae (fruit) 26. Eurya sp. (seed) 27. Aldrovanda vesiculosa (seed) 28. Corydalis sp. (seed) 29. Neillia sp. (endocarp) 30. Potentilla sp. (fruit) 31. Pyracantha sp. (endocarp) 32. Rubus sp. (endocarp) 33. Rosa sp. (endocarp) 34. Oxalis sp. (seed) 35. Acalypha sp. (seed) 36. Euphorbia sp. A (seed) 37. Mallotus philippenensis (seed) 38. Zanthoxylum sp. (seed) 39. Phyllanthus sp. (seed) 40. Meliosma sp. (endocarp) 41. Sabia sp. (endocarp) 42. Vitis sp. (seed) 43. Viola sp. (seed) 
Batrachium sp. (Fig. 3, No. 22)

Material studied: Fruit

Shape in outline obovate, elliptic, usually asymmetrical, $1.3 \mathrm{~mm}$ long and $0.8 \mathrm{~mm}$ wide. Adaxial margin straight, slightly convex or slightly concave; base rounded; slightly stipitate. Surface structure is lustrous, fine longitudinal striations are present on the surface..

Ecology: Occurs in open moist places.

Ranunculus sp. (Fig. 4, No. 23)

Material studied: Fruit

Shape in outline Ovoid, flat and lenticular, $2.4 \mathrm{~mm}$ long, $1.3 \mathrm{~mm}$ wide, with a thickened margin. The base of the style protrudes to a blunt spine. The surface structure is rough with finely striate markings.

Ecology: Occurs in open moist places.

Thalictrum sp. (Fig. 4, No. 24)

Material studied: Fruit

Shape in outline elliptic to lensoid, $2.4 \mathrm{~mm}$ long, $1.3 \mathrm{~mm}$ broad. Several longitudinal ribs are present running from base to apex. The base is slightly stipitate and the stipe is $0.2 \mathrm{~mm}$ long. Style is terminal, erect or slightly curved. The outer surface is glabrous, lusterless.

Ecology: Occurs in moist, shady as well as sunny places.

Ranunculaceae gen. et sp. indet. (Fig. 4, No. 25)

Material studied: Fruit

Shape in outline elliptic to lensoid with acute apex, 2.1 $\mathrm{mm}$ long and $1.1 \mathrm{~mm}$ wide. Surface black and lustrous. A big and rounded attachment scar is distinctly observed on the fruit.

Ecology: Occurs in shady as well as sunny places.

\section{THEACEAE}

Eurya sp. (Fig. 4, No. 26)

Material studied: Seed

Shape in outline circular to slightly angular, laterally flattened. The campylotropous seed is $1.4 \mathrm{~mm}$ long and 1.4 $\mathrm{mm}$ wide. The seed coat is composed of a thick sclerotic testa and a thin membranous tegmen. The outer epidermis of testa is composed of columnar cells. The seeds split into two equal halves revealing a horse shoe shaped embryo cavity which curves around the condyle.

Ecology: Part of the upland forest.

DROSERACEAE
Aldrovanda vesiculosa L. (Fig. 4, No. 27)

Material studied: Seed

Shape in outline ovoid, $1.5 \mathrm{~mm}$ long and $1.1 \mathrm{~mm}$ broad. The anatropous seed bears a short neck at the micropylar end and a slightly pointed chalaza. The raphe is marked by a slightly raised longitudinal ridge. The micropylar aperture is circular. The outer epidermis is black, shiny and formed from a layer of columnar sclereids.

Ecology: Growing in an aquatic environment.

\section{PAPAVERACEAE}

Corydalis sp. (Fig. 4, No. 28)

Material studied: Seed

Shape in outline, circular to reniform, $1.8 \mathrm{~mm}$ long and 1.5 $\mathrm{mm}$ wide. The campylotropous seed is more compressed, margin obtuse, hilum-cordate, rarely obovate, and centrally distinctly concave. The surface is glabrous, lustrous and smooth.

Ecology: Grows in damp and shady places.

\section{ROSACEAE}

Neillia sp. (Fig. 4, No. 29)

Material studied: Endocarp

Shape in outline ovoid, $1.9 \mathrm{~mm}$ long and $1.5 \mathrm{~mm}$ wide, the endocarps are generally brown to dark brown in external appearance. Surface smooth and lustrous with thick seed coat.

Ecology: Common taxa of mixed forests.

Potentilla sp. (Fig. 4, No. 30)

Material studied: Fruit (achene)

Shape in outline, ovate to elliptic-compressed, $0.9 \mathrm{~mm}$ long and $0.6 \mathrm{~mm}$ broad. The dorsal margin is semi-circular and the ventral margin is curved and slightly concave near the apex. The outer surface is almost smooth with fine outlines of small equiaxial sclerids and sometimes finger print like ridges also occur on the fruit surface.

Ecology: Common in the open field as well as on damp place.

Pyracantha sp. (Fig. 4, No. 31)

Material studied: Endocarp

The endocarp is one loculed, $3.5 \mathrm{~mm}$ long and $1.9 \mathrm{~mm}$ wide, endocarp is with straight ventral margin and semicircular dorsal margin. It is slightly pointed at the base and usually retuse at the base of the style, woody.

Ecology: Occurs in dry places. 

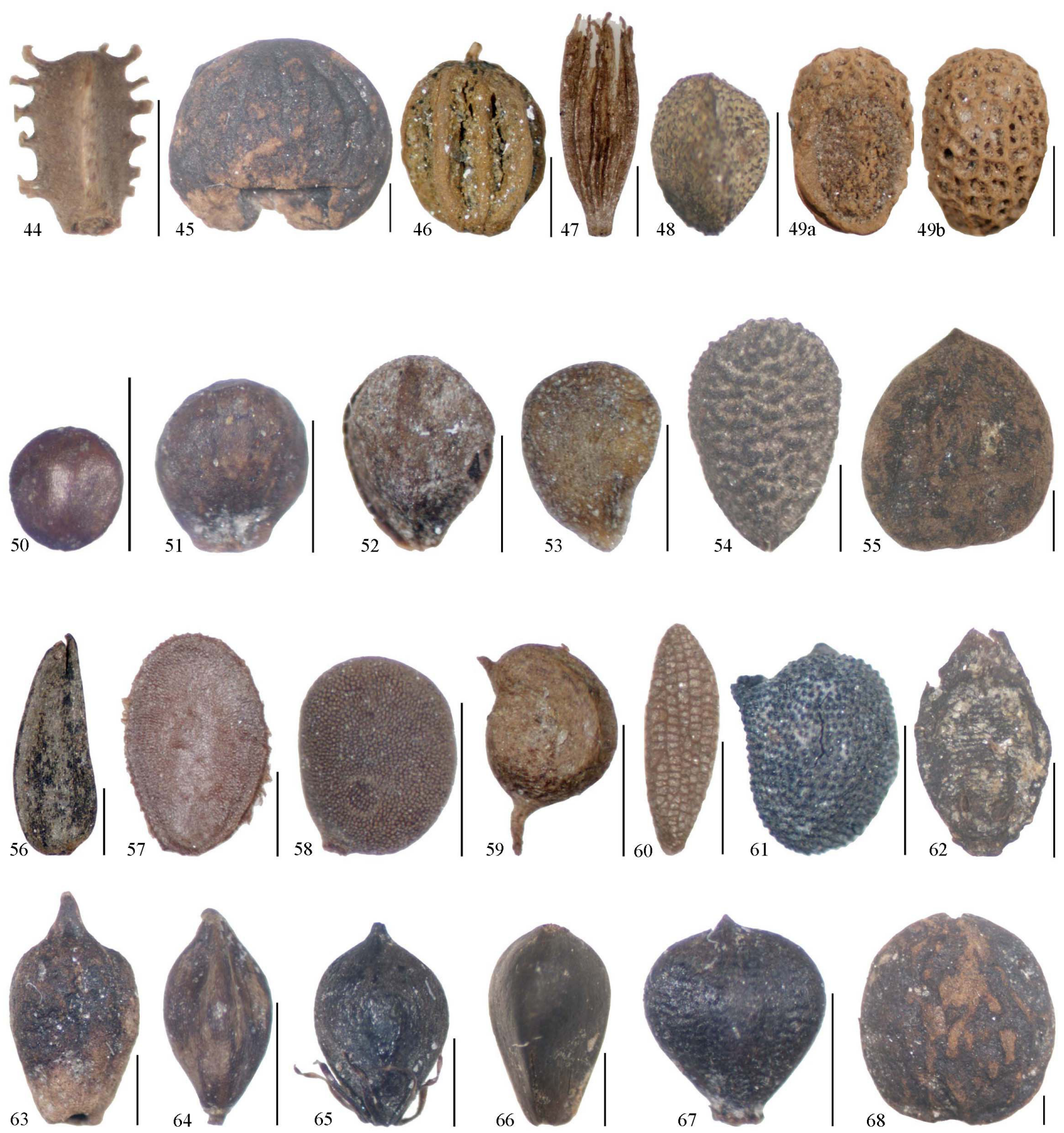

Scale $44-68: 1 \mathrm{~mm}$

Fig. 5: 44. Myriophyllum sp. (endocarp) 45. Cornus sp. (endocarp) 46. Oenanthe sp. (fruit) 47. Umbelliferae (fruit) 48. Lysimachia sp. (seed) 49. Ajuga sp. (fruit) 50. Clinopodium sp. (fruit) 51. Mosla sp. (fruit) 52. Labiatae (fruit) 53. Solanum nigrum (seed) 54. Sambucus sp. (endocarp) 55. Viburnum sp. (endocarp) 56. Compositae (fruit) 57. Nymphoides peltata (seed) 58. Nymphoides sp. (seed) 59. Potamogeton sp. (endocarp) 60. Naja sp. (seed) 61. Hypoxis aurea (seed) 62. Setaria sp. (fruit) 63. Sparganium sp. (endocarp) 64. Carex sp. (fruit) 65. Scirpus triqueter (fruit) 66. Scirpus cf. yagara (fruit) 67. Scirpus sp. (fruit) 68. Unknown (seed) 
Rubus sp. (Fig. 4, No. 32)

Material studied: Endocarp

Endocarp elliptic (kidney shaped) in outline and laterally flattened, $2.4 \mathrm{~mm}$ long and $1.5 \mathrm{~mm}$ wide. The base is rounded and the apex is bluntly narrowed and slightly curved inwards. The dorsal side is convex and the ventral side is concave near the apex. The surface has a polygonal mesh design with irregular ridges.

Ecology: Occurs in moist as well as sunny places.

Rosa sp. (Fig. 4, No. 33)

Material studied: Endocarp

Shape in outline triangular and flat, 3.7 long and $2.5 \mathrm{~mm}$ wide, some longitudinal markings are observed on the surface. Woody.

Ecology: Occurs in dry places.

\section{OXALIDACEAE}

Oxalis sp. (Fig. 4, No. 34)

Material studied: Seed.

The seed is ellipsoid-obovoid, $1.7 \mathrm{~mm}$ long and $0.9 \mathrm{~mm}$ wide, strongly laterally flattened, exariilate, apex obtuse and base acute. The surface of the seed is transversely or longitudinally ribbed. The ribs are irregular and varies in number from 6-10.

Ecology: Occurs in moist and shady places.

\section{EUPHORBIACEAE}

Acalypha sp. (Fig. 4, No. 35)

Material studied: seed

Shape in outline ovoid, $1.4 \mathrm{~mm}$ long and $1.0 \mathrm{~mm}$ broad, black. Chalazal area circular, raphe ventral, visible in close up view as a longitudinal pale suture running from chalazal area to aril. The fine striations are clearly observed on the seed surface.

Ecology: Occurs in open and dry places.

Euphorbia sp. A(Fig. 4, No. 36)

Material studied: seed

The seed is ellipsoid-obovoid, $2.6 \mathrm{~mm}$ long and $2.0 \mathrm{~mm}$ wide, surface lustrous, smooth with minute reticulation, chalazal area circular, Raphe distinct, ventral, visible as a longitudinal pale suture running from chalazal area to aril.

Ecology: Occurs in open and dry places.

Mallotus philippenensis (Lam.) Müll. Arg. (Fig. 4, No. 37)
Material studied: Seed

Shape in outline globose. The external surface of seed coat is rough and verrucose, curved palisade cells observed in the transverse section of seed coat is the characteristic feature of Euphorbiaceae.

Ecology: Occurs in subtropical forests.

Phyllanthus sp. (Fig. 4, No. 38)

Material studied: Seed

Seed elliptic to trigonous in outline, $2.9 \mathrm{~mm}$ long and 2.0 $\mathrm{mm}$ wide, surface smooth and lustrous. A big pore is distinct on the ventral portion of the seed. Minute and fine ornamentation is observed on the seed surface.

Ecology: Common taxa of tropical to subtropical zone.

\section{RUTACEAE}

Zanthoxylum sp. (Fig. 4, No. 39)

Material studied: Seed

Shape in outline globose, $3.8 \mathrm{~mm}$ long, $3.0 \mathrm{~mm}$ wide and $2.8 \mathrm{~mm}$ thick, both dorsal and ventral margin convex. Generally the seed surface is ornamented with reticulation but here the seed coat is covered by very thin cellulose. Raphe is distinct.

Ecology: Occurs in shady oak forests.

\section{SABIACEAE}

Meliosma sp. (Fig. 4, No. 40)

Material studied: Endocarp

Shape in outline subglobose and obovate in lateral view, $3.2 \mathrm{~mm}$ long and $2.6 \mathrm{~mm}$ broad. A circular funicular cavity or plug is prominent in the base. The surface of endocarp is roughly reticulated by very low ridges and a prominent median keel along the suture line.

Ecology: Common in shady oak forests.

Sabia sp. (Fig. 4, No. 41)

Material studied: Endocarp (incomplete)

The endocarp is obliquely reniform, laterally compressed, $5.3 \mathrm{~mm}$ long, $3.5 \mathrm{~mm}$ broad. The dorsal margin is convex and basal part is concave. The surface of lateral sides is reticulated randomly with thick ribs and interspaces of reticulum are rounded polygonal.

Ecology: Common in mixed and moist forests.

\section{VITACEAE}

Vitis sp. (Fig. 4, No. 42) 
Material studied: Seed

The anatropous seed is obovate in outline. $4.2 \mathrm{~mm}$ long, $3.5 \mathrm{~mm}$ broad. The micropylar part in the base of seed protrudes and is truncated. A raphe sinus runs vertically from lower part of the dorsal face into a rounded plug-like chalaza in the center of the ventral face. Two lanceolate grooves are prominent at both sides of raphe in dorsal side. Seed mostly pyriform with beaked base.

Ecology: Occurs in dry Oak forests.

VIOLACEAE

Viola sp. (Fig. 4, No. 43)

Material studied: Seed

Shape in outline obovoid, $1.7 \mathrm{~mm}$ long, $1.1 \mathrm{~mm}$ broad, anatropous seeds with the largest diameter close to the chalaza. The inner surface of the testa shows a transverse cellular pattern which is the characteristic feature. The seed surface is lustrous, usually indistinctly areolate. Apex is obtuse and the chalazal area circular.

Ecology: Growing as a weed in moist and open places.

\section{HALORAGACEAE}

Myriophyllum sp. (Fig. 5, No. 44)

Material studied: Endocarp

The endocarp is ovate in outline, $1.4 \mathrm{~mm}$ long, $0.9 \mathrm{~mm}$ broad, edge between dorsal and lateral surface is obtuse to angular. The external appearance of the surface is dull, glabrous. Outer margins fringed with tooth like appearances. Generally the seeds are open at one end.

Ecology: Plant of aquatic region.

\section{CORNACEAE}

Cornus sp. (Fig. 5, No. 45)

Material studied: Endocarp

Shape in outline ovoid to globose, $4.5 \mathrm{~mm}$ long and 4.0 $\mathrm{mm}$ broad. Surface with longitudinal ridges and grooves running all the way from bottom to top. Endocarp is thick and woody with lusterless surface.

Ecology: Commonly found in warm temperate forests.

\section{UMBELLIFERAE}

Oenanthe sp. (Fig. 5, No. 46)

Material studied: Fruit

Shape in outline oblong to obovate, $2.5 \mathrm{~mm}$ long and 2.0 $\mathrm{mm}$ broad. The fruit bears 3 dorsal and 2 lateral ribs, the lateral ribs is much larger than the dorsal ones. These ribs are alternate with lines of glossy material.
Ecology: Occurs in moist places.

Umbelliferae gen. et sp. indet. (Fig. 5, No. 47)

Material studied: Fruit

Shape in outline elongated, flat, $3.3 \mathrm{~mm}$ long and $1.1 \mathrm{~mm}$ wide. The seed surface is marked by several lengthwise ribs or ridges.

Ecology: Distributed in moist places.

PRIMULACEAE

Lysimachia sp. (Fig. 5, No. 48)

Material studied: Seed

The seeds are hemi-anatropous, elliptic or slightly angular in outline, $1.4 \mathrm{~mm}$ long and $1.1 \mathrm{~mm}$ broad. The hilum is marked by a narrow, elongated scar on the ventral crest. The outer layer is formed from light brown strongly projecting columnar cells with irregularly thickened cell walls. areas.

Ecology: Damp habitat, preferring riverside and swampy

\section{LABIATAE}

Ajuga sp. (Fig. 5, No. 49)

Material studied: Fruit

Shape in outline ovoid to ellipsoid, $2.1 \mathrm{~mm}$ long and 1.4 $\mathrm{mm}$ wide. The base is more or less triangular whereas apex is rounded. The dorsal surface bears rough reticulated structure whereas the ventral surface is almost covered with very big attachments.

Ecology: Usually occurs in shady places.

Clinopodium sp. (Fig. 5, No. 50)

Material studied: Fruit

Shape in outline rounded to triangular, $0.7 \mathrm{~mm}$ long and $0.6 \mathrm{~mm}$ wide, Surface reddish brown in colour and smooth, wall thin and brittle, minute slender attachment is distinct on the fruit.

Ecology: Usually occurs in shady places.

$$
\text { Mosla sp. (Fig. 5, No. 51) }
$$

Material studied: Fruit

The fruit is more or less spherical in outline, $1.3 \mathrm{~mm}$ long, $1.1 \mathrm{~mm}$ wide. The outer surface is woody, lusterless and finely reticulated with some thin white band of polygonal design.

Ecology: Occurs in shady and moist places. 
Labiatae gen. et sp. indet. (Fig. 5, No. 52)

Material studied: Fruit

Shape in outline rounded to triangular, $1.6 \mathrm{~mm}$ long and $1.3 \mathrm{~mm}$ broad. The surface of the fruit is smooth to horny, wall thin and brittle. The base is pointed whereas apex is somewhat rounded.

Ecology: Cosmopolitan in distribution.

\section{SOLANACEAE}

\section{Solanum nigrum L. (Fig. 5, No. 53)}

Material studied: Seed

Shape in outline triangular. The campylotropous seed is $1.6 \mathrm{~mm}$ long and $1.1 \mathrm{~mm}$ wide. The apex portion is more pointed whereas the basal part is flat and rounded. The seed surface bears reticular sculpture.

Ecology: Occurs in open places.

\section{CAPRIFOLIACEAE}

Sambucus sp. (Fig. 5, No. 54)

Material studied: Endocarp

Shape in outline elliptic to obovate, slightly tapered towards the base, $2.6 \mathrm{~mm}$ long and $1.6 \mathrm{~mm}$ broad, dorsioventrally flattened and slightly curved ventrally. The base of the endocarp has a small circular aperture. The surface is characterized by irregular, transverse undulations.

Ecology: Growing in moist and open places.

Viburnum sp. (Fig. 5, No. 55)

Material studied: Endocarp

Shape in outline flat and ovate, $3.6 \mathrm{~mm}$ long and $2.9 \mathrm{~mm}$ wide, with rounded lengthwise ridges and grooves; wall hard and thin. The surface is lusterless and woody.

Ecology: Occurs mostly in moist slope and also in open and sunny places.

\section{COMPOSITAE}

Compositae gen. et sp. Indet. (Fig. 5, No. 56)

Material studied: Fruit

Shape in outline oblong and elongated with terminal ring but pappus absent, compressed or flat, truncate at the top, often slightly curved sideways, $3.2 \mathrm{~mm}$ long and $1.2 \mathrm{~mm}$ wide. Fruit surface marked by longitudinal fine striations.

Ecology: Distributed in open and dry environment.

\section{Monocotyledons}

\section{GENTIANACEAE}

Nymphoides peltata (Gmel.) Kuntze (Fig. 5, No. 57)

Material studied: Seed

Shape in outline flat and oval with stiff marginal hairy edges, $3.6 \mathrm{~mm}$ long and $1.9 \mathrm{~mm}$ wide, surface lusterless.

Ecology: Plant of the aquatic environment.

Nymphoides sp. (Fig. 5, No. 58)

Material studied: seed

Seed flat and oval in outline, $1.4 \mathrm{~mm}$ long and $1.1 \mathrm{~mm}$ wide, Surface generally brown, smooth and shiny, a big attachment is distinct on the basal part. Minute granular ornamentation is distinct on the seed surface.

Ecology: Plant of the aquatic environment.

\section{POTAMOGETONACEAE}

Potamogeton sp. (Fig. 5, No. 59)

Material studied: Endocarp

Shape in outline earlike in appearance, $1.6 \mathrm{~mm}$ long, 1.1 $\mathrm{mm}$ wide. The lateral sides are flat with small depressions on the back. There is a spine in the middle, at the base there are about $1 \mathrm{~mm}$ long spine like projections on either side of the endocarp and a short spine on the lid of the germination pore, which also bears some short dent like spines.

Ecology: Aquatic plants distributed in the temperate and tropical areas.

\section{NAJADACEAE}

Najas sp. (Fig. 5, No. 60)

Material studied: Seed

Shape in outline elliptic-oblong, flat, somewhat pointed, narrowing into a short stalk at the base, $2.0 \mathrm{~mm}$ long and 0.6 $\mathrm{mm}$ broad. The seed coat is composed of an outer layer of thick walled cells with aquiaxial or slightly longitudinally elongate facets, arranged in about $15 \times 2$ longitudinal rows.

Ecology: Growing in an aquatic environment.

\section{HYPOXIDACEAE}

Hypoxis aurea Lour. (Fig. 5, No. 61)

Material studied: Seed

The seed is subglobose, $1.6 \mathrm{~mm}$ long, $1.2 \mathrm{~mm}$ broad, lusterless, rough, covered closely with papillae like projections and commonly with handle like structure. 
Ecology: Grassland vegetation.

\section{GRAMINEAE}

Setaria sp. (Fig. 5, No. 62)

Material studied: Fruit

Shpae in outline elongated and lensoid, $2.5 \mathrm{~mm}$ long and $1.5 \mathrm{~mm}$ wide. The fruit surface is finely transversely wrinkled or ridged. The presence of papillae on the surface of the fruit is the distinguishing properties of Setaria.

Ecology: Common taxa in wetland in flood plain and paddy fields.

\section{SPARGANIACEAE}

Sparganium sp. (Fig. 5, No. 63)

Material studied: Endocarp

Shape in outline ellipsoid to ovoid, $3.5 \mathrm{~mm}$ long and 2.0 $\mathrm{mm}$ broad. The base is rounded whereas the apex is pointed. Generally the endocarp contains four locule with few prominent longitudinal ridges, also bears a small opening at one end i.e. at the base. The endocarp bears a slight constriction in the waist like zone below the pithy tissue.

Ecology: Aquatic herbs of the temperate regions.

\section{CYPERACEAE}

Carex sp. (Fig. 5, No. 64)

Material studied: Fruit.

The fruit is biconvex and triangular in outline, $2.2 \mathrm{~mm}$ long, $1.2 \mathrm{~mm}$ wide, narrow tapering towards base and apex. Surface is spongy or coriaceous with minute pores.

Ecology: Streamside and marshy vegetation.

Scirpus triqueter L. (Fig. 5, No. 65)

Material studied: Fruit

Shape in outline ovate and triangular. The shape is circular to ovate with rounded base, $2.0 \mathrm{~mm}$ long, $1.2 \mathrm{~mm}$ wide. The style of the base is blunt or sometimes pointed too. The largest width is in the middle part of the fruit. The bristles are flat and about $1 \mathrm{~mm}$ in length. The number of bristles ranges from 6-8. The fruit surface is rough and lusterless.

Ecology: Streamside and marshy vegetation.

Scirpus cf. yagara (Fig. 5, No. 66)

Material studied: Fruit

Narrowly obovate to elliptic in outline, $3.2 \mathrm{~mm}$ long and $1.7 \mathrm{~mm}$ wide with an elongated beak on summit and with a well developed edge on abaxial side. Surface is smooth and black. Bristles are also present as in other species of Scirpus.

Ecology: Streamside and marshy vegetation.

Scirpus sp. (Fig. 5, No. 67)

Material studied: Fruit

Shape in outline ovate to triangular, $2.0 \mathrm{~mm}$ long, $1.5 \mathrm{~mm}$ wide. The base contains big attachment with bristles whereas the apex is cuneatly narrowed and pointed. The number of bristles ranges from 6-8. The surface consists of an epidermis with longitudinal rows of cells which is formed by schlerenchymatous fibres and is coriaceous; surface glabrous, lusterless.

Ecology: Streamside and marshy vegetation.

Unidentified specimen (Fig. 5, No. 68)

Material studied: Seed Shape in outline ovoid, $7.5 \mathrm{~mm}$ long and $6.7 \mathrm{~mm}$ broad, Seed surface contains undulating structure of patches distributed irregularly, woody.

\section{RESULTS OF PLANT MACROFOSSIL ANALYSIS}

Fossil assemblages from the Thimi section in Madhyapur contained 71 taxa belonging to 39 families. Those assemblages were characterized by the abundance of conifers. The common evergreen arboreal taxa such as Pinus, Picea and Tsuga were represented by the occurrence of fragments of leaves with petiole and tip, Abies with seed whereas Quercus was represented with cupules with nut. The deciduous taxa such as Alnus was represented by the occurrence of fruiting scale of infructescence, Carpinus with the nutlets, Cornus, Morus and Meliosma with endocarps, Magnolia with seeds. Eurya, an evergreen taxon and a component of lucidophyllous forest was represented by seed. Among the shrubs, Zanthoxylum, Pyracantha, Sambucus are the taxa that are mainly distributed in warm temperate areas where lucidophyllous forest are dominant. Sabia and Vitis are the woody vine taxa which are also the components of above mentioned forest. Herbaceous taxa include wetland and floodplain plants such as Persicaria hydropiper, Persicaria nepalensis, Persicaria scabra, Persicaria longiseta, Ranunculus, Myriophyllum, Potamogeton, Nymphoides, Oenanthe, Scirpus, Carex etc. The sporophytic plants, Selaginella remotifolia is distributed mainly on shady ground under forest. The compositions of seven plant macrofossil assemblages are as follows:

\section{Fossil assemblage T-1}

This macrofossil assemblage is characterized by the presence of fossils of fruit and seeds of shrubs, trees and herbaceous plants. The principal taxa present in this horizon are Eurya (9.6\%), Carpinus (6.8\%), Morus (1.2\%), Cornus 
Table 1: List of fruit and seed fossils from Madhyapur Thimi section of the Thimi Formation.

\begin{tabular}{|c|c|c|c|c|c|c|c|c|}
\hline \multirow{2}{*}{$\begin{array}{l}\text { Taxa with their Families } \\
\text { Pteridophyta } \\
\end{array}$} & \multirow[t]{2}{*}{ Part } & \multicolumn{7}{|c|}{ Sample Horizon in the Thimi Formation } \\
\hline & & \multirow[t]{2}{*}{ T1(\%) } & \multirow{2}{*}{$\begin{array}{l}\text { T2(\%) } \\
6(0.8) \\
\end{array}$} & \multirow[t]{2}{*}{\begin{tabular}{|l|} 
T3(\%) \\
\end{tabular}} & T4(\%) & T5(\%) & T6(\%) & $\mathrm{T} 7(\%)$ \\
\hline Selaginella remotifolia Spring (Selaginellaceae) & macrospore & & & & $10(4.2)$ & $17(1.0)$ & $12(1.2)$ & $1(0.1)$ \\
\hline Gymnospermae & & & & & & & & \\
\hline Taxus wallichiana Zucc. (Taxaceae) & seed & $2(0.1)$ & & & & $1(0.06)$ & & \\
\hline Abies sp. (Pinaceae) & seed & $4(0.2)$ & $1(0.1)$ & & $1(0.4)$ & & & \\
\hline Picea smithiana (Wall.) Boiss. (Pinaceae) & leaf & & & $4(3.2)$ & & & & \\
\hline Pinus roxburghii Sarg. (Pinaceae) & needle & $17(1.1)$ & $30(4.2)$ & $29(23.2)$ & $70(29.5)$ & $119(6.8)$ & & $6(0.5)$ \\
\hline Tsuga dumosa (D. Don) Eichler (Pinaceae) & leaf & $12(0.4)$ & $13(1.8)$ & $4(3.2)$ & $7(0.3)$ & $13(0.7)$ & & \\
\hline Angiospermae-Dicotyledonae & & & & & & & & \\
\hline Alnus sp. (Betulaceae) & fruit scale & $2(0.1)$ & & & & & & $4(0.3)$ \\
\hline Carpinus sp. (Betulaceae) & fruit & $110(6.8)$ & $23(3.2)$ & $6(4.8)$ & $13(5.5)$ & $46(2.6)$ & $27(2.8)$ & $1(0.1)$ \\
\hline Quercus sp. (Fagaceae) & fruit & $4(0.2)$ & & & & & & \\
\hline Morus sp. (Moraceae) & endocarp & $19(1.2)$ & $2(0.3)$ & & & $11(0.6)$ & $9(0.9)$ & \\
\hline Persicaria hydropiper (Meisn.) H. Gross (Polygonaceae) & fruit & $26(1.6)$ & & & & $15(0.9)$ & $15(1.6)$ & $18(1.4)$ \\
\hline Persicaria longiseta (Bruyn) Kitag. (Polygonaceae) & fruit & $2(0.1)$ & & & & $3(0.2)$ & & $17(1.4)$ \\
\hline Persicaria nepalensis (Meisn.) H.Gross (Polygonaceae) & fruit & $36(2.2)$ & $9(1.2)$ & $3(2.4)$ & $1(0.4)$ & $46(2.6)$ & $48(5.0)$ & $18(1.4)$ \\
\hline Persicaria sp. cf. P. Scabra (Polygonaceae) & fruit & $1(0.06)$ & & & & & $1(0.1)$ & $8(0.6)$ \\
\hline Rumex sp. (Polygonaceae) & fruit & & & & & $6(0.4)$ & & $4(0.3)$ \\
\hline Polygonum sp. (Polygonaceae) & fruit & $5(0.3)$ & $28(3.9)$ & $9(7.2)$ & $19(0.8)$ & & & $4(0.2)$ \\
\hline Stellaria sp. (Caryophyllaceae) & seed & $2(0.1)$ & $59(8.2)$ & & $22(9.2)$ & $65(3.7)$ & & \\
\hline Chenopodium album L. (Chenopodiaceae) & seed & $30(1.8)$ & $55(7.6)$ & $1(0.8)$ & $8(3.4)$ & $98(5.6)$ & $110(11.5)$ & $155(12.5)$ \\
\hline Magnolia sp. (Magnoliaceae) & seed & & & & & & & $1(0.1)$ \\
\hline Schisandra sp. A (Schisandraceae) & seed & $1(0.06)$ & & & & & & \\
\hline Schisandra sp. B (Schisandraceae) & seed & & & & & & & $1(0.1)$ \\
\hline Lauraceae gen. et sp. indet. & seed & $1(0.06)$ & $1(0.1)$ & & & & & \\
\hline Batrachium sp. (Ranunculaceae) & fruit & & $1(0.1)$ & & $3(3.1)$ & $18(1.0)$ & & \\
\hline Ranunculus sp. (Ranunculaceae) & fruit & $25(1.5)$ & $2(0.3)$ & & & $15(0.9)$ & $12(1.3)$ & $2(0.2)$ \\
\hline Thalictrum sp. (Ranunculaceae) & fruit & $2(0.1)$ & $5(0.7)$ & & $1(0.4)$ & $6(0.4)$ & $5(0.5)$ & \\
\hline Ranunculaceae gen. et sp. indet. & fruit & & & & & & $1(0.1)$ & \\
\hline Eurya sp. (Theaceae) & seed & $154(9.3)$ & $32(4.5)$ & & $15(6.3)$ & $175(10.0)$ & $272(28.5)$ & $15(1.2)$ \\
\hline Aldrovanda vesiculosa L. (Droseraceae) & seed & $3(0.2)$ & & & & & & $1(0.1)$ \\
\hline Corydalis sp. (Papaveraceae) & seed & $1(0.06)$ & & & & $12(0.7)$ & $3(0.3)$ & \\
\hline Neillia sp. (Rosaceae) & seed & $1(0.06)$ & & & & $2(0.1)$ & $3(0.3)$ & \\
\hline Potentilla sp. (Rosaceae) & fruit & $185(11.2)$ & $76(10.6)$ & $51(40.8)$ & $26(11.0)$ & $156(8.8)$ & & \\
\hline Pyracantha sp. (Rosaceae) & endocarp & $54(3.3)$ & $16(2.2)$ & $3(1.6)$ & & $6(0.4)$ & $15(1.6)$ & \\
\hline Rubus sp. (Rosaceae) & endocarp & $88(5.3)$ & $40(5.6)$ & $4(3.2)$ & $16(6.7)$ & $93(5.3)$ & $80(8.4)$ & $21(1.7)$ \\
\hline Rosa sp.(Rosaceae) & endocarp & $1(0.06)$ & & & & & & \\
\hline Oxalis sp. (Oxalidaceae) & seed & $13(0.8)$ & $7(1.0)$ & & $1(0.4)$ & $13(0.7)$ & $7(0.7)$ & $4(0.3)$ \\
\hline Acalypha sp. (Euphorbiaceae) & seed & $5(0.3)$ & $2(0.3)$ & $1(0.8)$ & $5(2.1)$ & & $4(0.4)$ & \\
\hline Euphorbia sp. A (Euphorbiaceae) & seed & $31(1.9)$ & $6(0.8)$ & & & $1(0.06)$ & & \\
\hline Euphorbia sp. B (Euphorbiaceae) & seed & & & & & & & $2(0.2)$ \\
\hline $\begin{array}{l}\text { Mallotus philippenensis (Lam.) Müll. Arg. } \\
\text { (Euphorbiaceae) }\end{array}$ & seed & $3(0.2)$ & $1(0.1)$ & & & & & \\
\hline Phyllanthus sp. (Euphorbiaceae) & seed & $5(0.3)$ & & & & $1(0.06)$ & & \\
\hline Zanthoxylum sp. (Rutaceae) & seed & & $1(0.1)$ & $2(1.6)$ & & & & \\
\hline Meliosma sp. (Sabiaceae) & endocarp & $1(0.06)$ & & & & & & \\
\hline Sabia sp. (Sabiaceae) & endocarp & $1(0.06)$ & & & & & & \\
\hline Vitis sp. (Vitaceae) & seed & $23(1.4)$ & $1(0.1)$ & & & & & $4(0.3)$ \\
\hline Daphne sp. (Thymelaeaceae) & seed & & & & & $1(0.06)$ & & \\
\hline Viola sp. (Violaceae) & seed & $16(1.0)$ & $21(2.9)$ & & $1(0.4)$ & $4(0.2)$ & $12(1.3)$ & $4(0.3)$ \\
\hline Myriophyllum sp. (Haloragaceae) & endocarp & $16(1.0)$ & $1(0.1)$ & & & $4(0.2)$ & $4(0.4)$ & $11(0.9)$ \\
\hline Cornus sp. (Cornaceae) & endocarp & $18(1.1)$ & & & & $3(0.2)$ & & \\
\hline Oenanthe sp. (Umbelliferae) & fruit & $4(0.2)$ & $15(2.1)$ & & $3(1.3)$ & $2(0.1)$ & & \\
\hline Umbelliferae gen. et sp. indet. & fruit & $4(0.2)$ & $10(1.4)$ & $4(3.2)$ & $6(2.5)$ & $10(0.6)$ & $4(0.4)$ & $4(0.3)$ \\
\hline Lysimachia sp. (Primulaceae) & seed & $4(0.2)$ & $1(0.1)$ & & & $14(0.8)$ & $2(0.2)$ & \\
\hline Ajuga sp. (Labiatae) & fruit & $8(0.5)$ & $1(0.1)$ & & & $2(0.1)$ & $4(0.4)$ & \\
\hline Clinopodium sp. (Labiatae) & fruit & & & & & $72(4.1)$ & & \\
\hline Mosla sp. (Labiatae) & fruit & $15(0.9)$ & & & & & $1(0.1)$ & \\
\hline Labiatae gen. et sp. indet. & fruit & & & & & & $1(0.1)$ & $1(0.1)$ \\
\hline Solanum nigrum L. (Solanaceae) & seed & & & $1(0.8)$ & $1(0.4)$ & & & \\
\hline Sambucus sp. (Caprifoliaceae) & endocarp & $3(0.2)$ & & & $1(0.4)$ & & $7(0.7)$ & $250(20.2)$ \\
\hline Viburnum sp. (Caprifoliaceae) & endocarp & $8(0.5)$ & $1(0.1)$ & $2(1.6)$ & $1(0.4)$ & $12(0.7)$ & $3(0.3)$ & \\
\hline Compositae gen. et sp. indet. (Compositae) & fruit & $3(0.2)$ & & $1(0.8)$ & & & & \\
\hline Angiospermae-Monocotyledonae & & & & & & & & \\
\hline Nymphoides peltata (Gmel.) Kuntze (Gentinaceae) & seed & & $3(0.4)$ & & & & & \\
\hline Nymphoides sp. (Gentianaceae) & seed & $18(1.1)$ & & & & & & \\
\hline Gentianaceae gen. et sp. indet. & seed & $20(1.2)$ & & & & $190(10.8)$ & $97(10.1)$ & $5(0.4)$ \\
\hline Potamogeton sp. (Potamogetonaceae) & endocarp & $23(1.4)$ & $11(1.5)$ & & $1(0.4)$ & $6(0.3)$ & $13(1.4)$ & $3(0.2)$ \\
\hline Najas sp. (Najadaceae) & seed & & & & & $1(0.06)$ & & $1(0.1)$ \\
\hline Hypoxis aurea Lour. (Hypoxidaceae) & seed & & & & & $1(0.06)$ & & \\
\hline Setaria sp. (Gramineae) & fruit & & $3(0.4)$ & $1(0.8)$ & & & & \\
\hline Sparganium sp. (Typhaceae) & endocarp & $9(0.5)$ & $8(1.1)$ & $2(1.6)$ & & $5(0.3)$ & $12(1.2)$ & \\
\hline Carex sp. (Cyperaceae) & fruit & $23(1.4)$ & $200(27.8)$ & & & $400(22.8)$ & & \\
\hline Scirpus triquetor L. (Cyperaceae) & fruit & $550(33.30)$ & $22(3.0)$ & & $5(2.1)$ & $59(3.4)$ & $108(11.3)$ & $605(48.8)$ \\
\hline Scirpus cf. yagara (Cyperaceae) & fruit & $2(0.1)$ & & & & & $1(0.1)$ & \\
\hline Scirpus sp. (Cyperaceae) & fruit & $38(2.3)$ & $7(1.0)$ & & & $33(1.9)$ & $64(6.7)$ & $50(4.0)$ \\
\hline Unidentified & seed & & & & & & & $1(0.1)$ \\
\hline Total count & & 1653 & 719 & 125 & 237 & 1757 & 955 & 1240 \\
\hline
\end{tabular}


(1.1\%), Rubus (5.5\%), Pyracantha (3.3\%). The gymnosperm taxa include Pinus (>1\%), Abies, Tsuga and Taxus $(<1 \%)$. Of the herbs, Scirpus triqueter (34\%) and Potentilla (11.4\%) are the dominant species. The other common herbs are Chenopodium album, Persicaria hydropiper, Persicaria nepalensis, and species of Ranunculus, Scirpus, Potamogeton, Myriophyllum, Nymphoides etc.

\section{Fossil assemblage T-2}

This fossil assemblage is characterized by the increase in gymnosperms taxa as Pinus (4.2\%), Tsuga (1.8\%) and Abies $(<1 \%)$. The angiosperm taxa are represented by Carpinus (3.2\%), Eurya (4.5\%), Pyracantha (2.2\%), Rubus (5.6\%) etc. Among the herbs, Carex (27.8\%) is the most dominant taxa. The other major herbaceous plants are Potentilla $(10.6 \%)$, Chenopodium album (7.6\%), Stellaria (8.2\%), Polygonum (3.9\%), Viola (2.9\%), Oenanthe (2.1\%), and Scirpus triqueter (3\%).

\section{Fossil assemblage T-3}

This fossil assemblage is represented by the abrupt increament in the percentage of conifers with the dominance of Pinus (23.2\%), Picea and Tsuga with (3.2\%) each. The angiosperms are very less in total count with Carpinus (4.8\%), Rubus (3.2\%), Viburnum and Zanthoxylum with $(1.6 \%)$ each. Among the herbs, Potentilla $(40.8 \%)$ is the most dominant taxon in this horizon. The other common herbs are Polygonum (7.2\%), Persicaria nepalensis (2.4\%), Compositae (3.2\%) and Sparganium (1.6\%). Solanum, Chenopodium album, Acalypha, Setaria are with less than $1 \%$ each.

\section{Fossil assemblage T-4}

This fossil assemblage is characterized by the high percentage of gymnosperms taxa. Pinus reach to its maximum with $29.5 \%$. The other conifers are Abies and Tsuga are with $(<1 \%)$ each. The angiosperms taxa abruptly decrease with Carpinus (5.5\%), Eurya (6.3\%), Rubus (6.7\%). Among the herbs, Potentilla $(11 \%)$ is the major taxa in this horizon. Stellaria (9.2\%), Compositae (2.5\%), Batrachium (3.1\%), Chenopodium album (3.4\%), Acalypha (2.1\%) and Oenanthe $(1.3 \%)$ are the principal constituents. Solanum, Viola, Thalictrum, Potamogeton etc are represented in less amount. The sporophytic plants, Selaginella remotifolia is also the important taxa with (4.2\%). Gentianaceae, Potamogeton, Myriophyllum, Najas etc. are the common aquatic herbs.

\section{Fossil assemblage T-5}

This fossil assemblage is represented by the decrease in gymnosparms taxa and increase in angiosperms. Of the gymnosperms, Pinus $(6.8 \%)$ is again the principal constituent and Tsuga and Taxus with $(<1 \%)$ each. The major angiosperm taxa are Carpinus (2.7\%), Eurya (10.4\%), Rubus (5.5\%). The other common taxa are Viburnum, Morus, Cornus, Pyracantha and Phyllanthes with $(<1 \%)$ each. The herbaceous taxa also increses in this horizon. Among the herbs, Carex (23.7\%) is the most dominant taxa. Potentilla is the other principal constituents with $(9.2 \%)$. The other common herbaceous taxa are Chenopodium album (5.8\%), Stellaria $(3.8 \%)$, Scirpus triqueter (3.5\%), Persicaria nepalense (2.7\%), Scirpus (2\%). The other least common herbs are Batrachium, Ranunculus, Thalictrum, Viola, Oxalis, Lysimachia, etc. with $(<1 \%)$ each.

\section{Fossil assemblage T-6}

In this macrofossil assemblage, the conifers are totally absent. Of the angiosperms, Eurya (28.5\%), Rubus (8.4\%), Carpinus $(2.8 \%)$ are the principal taxa. The other common taxa are Pyracantha, Viburnum, Morus and Sambucus. Potentilla, the most common herbaceous taxa throughout the underlying horizons is totally absent here. The most common herbs are Chenopodium album (11.5\%), Scirpus triqueter (11.3\%), Scirpus (6.7\%), Persicaria nepalensis (5\%), Persicaria hydropiper (1.6\%), Ranunculus and Viola (1.3\%), Sparganium (1.2\%) and Potamogeton (1.4\%). The other less common herbs are Corydalis, Acalypha, Ajuga, Oxalis, Lysimachia, Myriophyllum etc. Selaginella remotifolia is also the important taxa with $1.2 \%$ of the total count.

\section{Fossil assemblage T-7}

In this fossil assemblage, the conifers again reappear with Pinus in very less quantity. Among the angiosperms, Sambucus (20\%) increases abruptly which is the most dominant woody angiosperm taxa in this horizon followed by Rubus (1.7\%) and Eurya (1.2\%). The other less common woody angiosperms are Carpinus, Alnus, Viburnum with $(<1 \%)$ each. Among the herbs Chenopodium album $(12.5 \%)$ is the most common taxa. The other common herbs are Scirpus (4\%), Persicaria nepalensis, Persicaria hydropiper, Persicaria longiseta type with (1.4\%) each. Scirpus triqueter $(48.8 \%)$ is the most dominant herbaceous taxa in this horizon. The aquatic herbs are Myriophyllum, Najas, Nymphoides, Potamogeton with $<1 \%$ each.

\section{PALAEOCLIMATIC INTERPRETATION}

The plant macrofossils obtained from the Thimi Formation give a clear picture of the vegetation growing around the depositional basin. From the analysis of paleocarpoflora, we have generated some idea about the paleovegetation and paleoclimate during the time of deposition of the Thimi Formation. The conifers are common throughout the section except for T-6. Pinus is the most dominant taxa whereas Abies, Picea, Tsuga and Taxus are the common taxa within the gymnosperms. Of the angiosperms, Carpinus, Eurya, Rubus, Viburnum, Morus and Pyracantha are the common taxa. Sambucus is partly present in the lower horizons but abundant in the uppermost horizons. Of the herbs, Potentilla is the most dominant taxa throughout the section except at the top. Chenopodium album, Persicaria nepalensis, Persicaria hydropiper, 
Ranunculus, Stellaria are the common taxa throughout all the horizons. Potamogeton, Myriophyllum, Nymphoides, Scirpus triqueter, Scirpus and Carex are the common elements of the wetland area.

The representation of conifers like Pinus, Abies, Tsuga and Taxus in the lowermost horizon T-1 shows the cold phase but Quercus, Carpinus are the taxa representing the warm phase though their composition is not so high. The subtropical element, Eurya is one of the major constituents of this horizon. From these information it is noted that there was not uniformity in the climate. This horizon might have been deposited in subtropical to warm temperate climatic condition.

There were some changes in the horizon T-2. There was an increment in the constituents of gymnosperms but decrease in angiosperms taxa. The composition of Pinus and Tsuga were increased whereas the warm climatic taxa such as Carpinus, Pyracantha were decreased. Quercus was totally absent. There was also the decline in the Eurya which is one of the major element of the subtropical climate. So it can be considered that this horizon was deposited in warm to cold temperate phase. The occurrence of cold climate is also supported by the high percentage of herbaceous plants. There was major change in the horizon T-3. The gymnosperms were the most dominant taxa with the very few representation of woody angiosperms. Pinus (23.2\%) along with Picea, and Tsuga were the dominant taxa from this horizon. The warm climatic taxa such as Carpinus and Pyracantha were present in few amount. The subtropical element Eurya was totally absent. By the dominance of gymnosperms over the warm climatic angiosperms and totally absent of subtropical element, it is confirmed that this horizon was deposited in cold temperate condition.

There was minor change in the horizon T-4. The conifers were still in the ascending position than that of T-3. Pinus (29.5\%) along with Abies and Tsuga was the dominant taxa in this horizon. There was slight increase in the warm climatic taxa Carpinus. The subtropical element Eurya which was absent in the underlying horizon again reappeared. The dominance of gymnosperms, slightly increase in the warm climatic taxa and also the reappearance of subtropical element, it is considered that there was some fluctuation in climate than that of the lower horizon from cold temperate phase to warm temperate phase.

There was some major change in horizon T-5. The conifers dramatically decreased with Pinus $(6.8 \%)$ and Tsuga and Taxus $(<1 \%)$. The subtropical element Eurya was the major component from the woody angiosperms. Many more angiosperms reappeared with few seed-fruit remains. The decline in gymnosperms and with slight increase in angiosperm and also the representation of subtropical element, it is considered that there was again fluctuation of climate from warm temperate phase to subtropical phase during the period of deposition.

In the horizon T-6, the gymnosperms were completely absent and the subtropical element like Eurya (28.5\%) emerges abruptly along with Rubus (8.4\%). The representation of Carpinus, Pyracantha and other herbaceous plant still indicates the warm climate. This horizon might have been deposited during the subtropical to warm climatic phase. This horizon was considered to be the most warm phase from this section of the Thimi Formation.

There was again the major change in horizon T-7 with the reappearance of conifers though their constituent is very less. Eurya, the subtropical climatic taxa has declined from $28.5 \%$ to $1.2 \%$. Sambucus $(20.2 \%)$ was the only major woody angiosperm present in this horizon. The herbaceous wetland taxa are abundantly present and the principal contributors were Scirpus triqueter (48.8\%) and Polygonaceae. The reappearance of conifers and decline in warm and subtropical taxa shows the fluctuation of climate from the most warm phase to moderately warm to cold phase in this horizon than that of the underlying horizon.

Paudayal (2005) had done a detailed palynological investigation from the same section of the Thimi Formation. According to the result obtained from the pollen analysis, the conifers were dominant over the woody angiosperms. Pinus was the most common taxa within the gymnosperms. Picea, Abies, Tsuga were the other common gymnosperms. Of the woody angiosperms, Quercus cf. lepidobalanopsis (i.e. $Q$. semecarpifolia, $Q$. lamellosa), the cold temperate taxa were abundantly present followed by Alnus, Betula, Corylus etc. Castanopsis, the subtropical element which was abundantly present in the underlying Gokarna Formation was represented in trace amount only. In overall, the pollen result suggested that with the dominance of conifers and the present of Quercus cf. lepidobalanopsis in major amount, the climate around the depositional basin was warm to cold temperate during the Late Pleistocene.

By comparing the present plant macrofossil data with the pollen result, we have generated similar interpretation. Gymnosperms were the dominant taxa over the angiosperms. Like pollen result, Pinus was the most common taxa within the conifers. These taxa were present in minor amount in lower horizons, abundant in the middle horizons and virtually absent in the upper horizons. The subtropical element like Eurya represented as the major constituents in the lower horizon, absent or very few in the middle and again the reappearance and dominance in the upper horizons. So, from all these result, we have confirmed that the climate around the depositional basin was not uniform. There was fluctuation of climate from warm temperate to cool temperate and again to subtropical 
to warm temperate to moderately cold temperate phase during the deposition of the Thimi Formation.

A detailed plant macrofossil analysis was performed from the underlying Gokarna Formation at Dhapasi in which the subtropical and warm climatic taxa such as Eurya, Ficus and Ziziphus were dominant over the cold climatic taxa Abies, Tsuga, Betula (Bhandari et al. 2009). On comparing the result obtained from Thimi with that of Dhapasi, it is confirmed that there was major change in vegetation around the depositional basin. The subtropical and warm temperate type of vegetation might have shift to warm to cold temperate type with the abundant presence of conifers and other evergreen taxa in the Thimi section.

\section{CONCLUSIONS}

The macro-fossil analysis from the Madhyapur Thimi section of the Thimi Formation suggested that the climate around the depositional basin was not uniform. Based on the study of 71 taxa from 39 families, the climatic parameters were reconstructed. The presence of conifers, representation of warm climatic taxa such as Quercus, Carpinus also the present of subtropical element like Eurya suggests the climate to be warm in the lower horizons. The dominance of gymnosperms over angiosperms suggests the cool temperate climate in the middle horizons (T-3 and T-4). The decrease in conifers and reappearance of subtropical element like Eurya suggests the minor change in climate from cold temperate to warm to moderately cold temperate phase during the deposition of horizon T-5. The complete absence of conifers and dominance of Eurya reveals again the change of climate from warm-cold temperate phase to subtropical to warm phase during the deposition of horizon T-6 and this time period is considered to be the most warm phase during the deposition of Thimi Formation. The reappearance of conifers and decline in subtropical taxa suggest the minor change in climate from the warm phase to moderately cold phase during the deposition of uppermost horizon i.e.T-7. The characteristic feature of the Thimi Formation is the dominance of gymnosperms and herbaceous taxa over the woody angiosperms except in the middle upper horizon.

\section{ACKNOWLEDGEMENTS}

We thank the Chiba University, Chiba and Paleo-Labo Company Ltd. Saitama, Japan for providing laboratory facilities to conduct this research. We should like to thank Dieter Uhl (Senckenberg Research Institute and Natural History Museum, Frankfurt am Main, Germany) and Edoardo Martinetto (University of Torino, Italy) for their valuable suggestions for improving the manuscript. Thanks are also extended to K. K. Shrestha and R. P. Chaudhary (Central Department of Botany, Tribhuvan University) for reviewing the manuscript and providing the list of corrections. This research is partly supported by the grant from Nepal Academy of Science and Technology (NAST).

\section{REFERENCES}

Bhandari, S., Momohara, A., and Paudayal, K. N., 2009, Late Pleistocene plant macro-fossils from the Gokarna Formation of the Kathmandu Valley, Central Nepal. Bull. the Dept. Geol., Tribhuvan University, Kathmandu, Nepal, v. 12, pp. 75-88.

Fujii, R. and Sakai, H., 2001, Paleoclimatic changes during the last 2.5 Myr recorded in the Kathmandu Basin, Central Nepal Himalayas. Jour. Asian Earth Sci., v. 20, pp. 255-266.

Gajurel, A. P., 1998. Géochimie isotopique et déformations synsédimentares des dépots du basin de Kathamandu. Memoire de DEA de l'Universite de Grenoble, 30 p.

Gajurel, A. P., Huyghe, P., France-Lanord, C., Mugnier, J. L., Uprety, B. N., and Le Fort, P., 1998, Seismites in the Kathmandu basin, Jour. Nepal Geol. Soc., v. 18, pp. 125-134.

Igarashi, Y., Yoshida, M., and Tabata, H., 1988, History of Vegetation and Climate in the Kathmandu Valley. Proc. Indian Natn. Sci. Acad., v. 54A(4), pp. 550-563.

Malla, S. B., Rajbhandary, S. B., Shrestha, T. B., Adhikari, P. M., Adhikari, S. R., and Shakya, P. R., (Eds.), 1986, Flora of Kathmandu Valley. Bulletin of the Department of Medicinal Plants, No. 11. 962 p.

Martin, A. C. and Barkley, W. D., 1973, Seed Identification Manual. The Blackburn Press, New Jersey. 221 p.

Nakagawa, T., Yasuda, Y., and Tabata, H., 1996, Pollen morphology of Himalayan Pinus and Quercus and its importance in palynological studies in Himalayan area. Review of Playobotany and Palynology, v. 91, pp. 317-329.

Ooi, N., 2001, Last Glacial plant macrofossils discovered in the Kathmandu Valley, Nepal. Japanese Journal of Historical Botany, v.10, pp.1.

Paudayal, K. N. and Ferguson, D. K., 2004, Pleistocene Palynology of Nepal. Quaternary International, v. 117, pp. 69-79.

Paudayal, K. N., 2005, Late Pleistocene Pollen Assemblages from the Thimi Formation, Kathmandu Valley, Nepal. The Island Arc, v. 14 (4) pp. 328-337.

Paudayal, K. N., 2006, Late Pleistocene Pollen Assemblages from the Gokarna Formation, Kathmandu Valley, Nepal. Jour. Nepal Geol. Soc., v. 33, pp. 33-38.

Press, J. R., Shrestha, K. K., and Sutton, D. A., 2000, Annotated Checklist of the Flowering Plants of Nepal. The Natural History Museum, London, $430 \mathrm{p}$.

Rai, S. M., Guillot, S., Le Fort, P., and Upreti, B. N., 1998, Pressure temperature evolution in the Kathmandu and Gosainkund regions, central Nepal. Jour. Asian Earth Sci., v. 16 , pp. 283-298.

Sakai, H., Fujii, R., Kuwahara, Y., Uprety, B. N., and Shrestha, S.D., 2001, Core drilling of the basin fill sediments in the the Kathmandu Valley for paleoclimatic study: preliminary results. Jour. Nepal Geol. Soc., v. 25, (Sp. Is.), pp. 9-18.

Sakai, H., Fujii, R., and Kuwahara, Y., 2002, Changes in the depositional system of the Paleo-Kathmandu Lake caused by uplift of the Nepal Lesser Himalaya. Jour. Asian Earth Sci., v. 20, pp. 267-276.

Stainton, J. D. A., 1972, Forests of Nepal. John Murray, London, $181 \mathrm{p}$.

Stöcklin, J. and Bhattarai, K. D., 1977, Geology of the Kathmandu area and Central Mahabharat range, Nepal 
Himalaya. Report of Department of Mines and Geology/ UNDP (unpublished report), $86 \mathrm{p}$.

Yoshida, M. and Gautam, P., 1988, Magnetostratigraphy of Plio-

Pleistocene lacustrine deposits in the Kathmandu Valley,
Central Nepal, Proc. Indian Natn. Sci. Acad., v. 54A(30), pp. 410-417.

Yoshida, M. and Igarashi, Y., 1984, Neogene to Quaternary Lacustrine sediments in the Kathmandu Valley, Nepal. Jour. Nepal Geol. Soc., v. 4, pp. 73-100. 